\title{
Diagnosing resistance to change in the change management process
}

\section{Tetiana Kuzhda}

Ternopil Ivan Pul'uj National Technical University,

Ruska str., 56, Ternopil, 46001, Ukraine

PhD, Associate Professor, Faculty of economics and management

OPEN (access C) doi)

Article history:

Received: November, 2016

1st Revision: November,

2016

Accepted: November, 2016

\section{JEL classification:}

J53

DOI:

10.14254/jems.2016.1-1.5

\begin{abstract}
This article explains the change management process and resistance to organizational change through examining causes of resistance to change, diagnosing them, and finding the ways to deal with resistance to change. In business environment, the one thing any company can be assured of is change. If an organization experiences change it may also need to implement new business strategies, which can create resistance among employees. Managers need to know in which phase they have to expect unusual situations, problems, and resistance to change. Most successful organizations are those that are able to adjust themselves to new conditions quickly. Preparing for change, managing change through resistance management plan and reinforcing change have been identified in the article as the main phrases of change management process that lead to improve the organization performance. Managing resistance to change is important part for success of any change effort in each company. Dealing with resistance in large part will depend on timely recognition of the real causes of resistance to change and finding the ways to reduce, overcome or eliminate the resistance to change. Developing efficient ways to introduce and implement change can ease the stress the staff feels when change is introduced. Different resistance states, causes of change resistance and forms of change resistance have been emphasized in the change management process. The proposed diagnosing model has been used to identify significant and weighty causes of resistance to change by using the expert survey and ranking causes of resistance to change. The ways to reduce and overcome resistance to change have been explained.
\end{abstract}

Keywords: change management process, resistance to organizational change, change management tools, causes of resistance to change and types of resistance. 


\section{Introduction}

In order to successfully manage change processes, it is necessary to analyze the phases of this process, identify the causes of resistance to change and diagnose the resistance to change. Managers need to know in which phase they have to expect unusual situations, problems, and resistance to change. Most successful organizations are those that are able to adjust themselves to new conditions quickly. This requires preparing for change, managing change through resistance management plan and reinforcing change that lead to improve the organizational effectiveness.

Change is any alteration occurring in the work environment that affects the way in which employees will act. These changes may be planned or unplanned, catastrophic or evolutionary, positive or negative, strong or weak, slow or rapid stimulated either internally or externally. In times of change, the natural employee reaction is to resist. It is normal to experience resistance whenever there is change. In the current climate many companies are dealing with difficult situations and resistance types while implementing changes. They need to understand different resistance states such as cognitive, emotional and behavioural, and identify the causes of change resistance and forms of change resistance. Managing resistance to change is important part for success of any change effort in each company. Dealing with resistance in large part will depend on timely recognition of the real causes of resistance to change and finding the ways to reduce, overcome or eliminate the resistance to change. Developing efficient ways to introduce and implement change can ease the stress the staff feels when change is introduced, and it can also help the vendors, customers and business partners adjust to any changes in the way an organization does business.

\section{Literature review}

Many authors such as Pashchenko (2014), Lysun and Mikh (2015) focus on implementing change process through different organizational change models: Lewin's Organizational Change Model, Seven S Framework Model, ADKAR Organizational Change Model or Bullock and Batten's Integrative model for Change and insist on their use in domestic practice. Each of these models allows change management teams to focus their activities on specific business results. However, none of them explains in detail how to diagnose and overcome resistance to change. The other authors (Oleksiv, \& Lisovych, 2013) considers the evolutionary stages of organizational changes implementation at enterprises from the mid- of the XX century until now. They single out the main areas of organizational changes implementation in enterprise control system and note that efficiency of enterprise development directions depends on company's capacities, both financial and technical and raising funds from external sources, and combining companies into clusters. Their studies does not pay enough attention to the employee actions when they perceive that a change that is occurring as a threat to them.

Also, the literature review indicates that a plenty number of change initiatives are unsuccessful and the researchers generally agree that employee resistance is one of the leading causes for the failure of change initiatives (McCalman, Paton, \& Siebert, 2016). A few studies examine how employees emotionally react to and deal with changes and which role their emotion regulation has in dealing with organizational change (Cummings, Worley, 2009). The other scientists emphasize that it is important to pay attention to employees' emotions and how employees express and regulate these emotions, because this can have an impact on the acceptance of a situation (Kondalkar, 2013), on job satisfaction, and the intention to leave the organization (Harigopal, 2006). Reiss (2012) emphasizes the core features of the approach to managing change such as balancing and blending. His study is focused on managing two categories of barriers: the barriers to success as a contribution to opportunity management and the barriers to failure as a contribution to risk management. The author believes that the blending of management tools is used to handle different risks (due to resistance, inertia or confusion) and opportunities in change projects.

We can conclude that the most authors have examined the organizational change implementation models and they have not yet conducted a detailed research of resistance change in the change management process.

The main aim of this article is to develop diagnosing model of resistance to change and explain its practical use. The objectives are the following: to explain the change management process and resistance to organizational change through examining causes of resistance to change, diagnose them, and find the ways to deal with resistance to change. At first we will examine the change management process steps and identify the phase where we can expect the resistance to change and manage change by using some tools such as resistance management plan. Also, we will 
point out the main metrics which a manager can use to track change management process effectiveness. Within the current study we will examine the cognitive state, emotional state and behavioural state of resistance to change and forms and causes of change resistance as well.

The applied methods used in this study is the expert survey through examining the experts answer questionnaires, selecting and ranking causes of resistance to change and the methods to deal with organizational change resistance.

\section{Key research findings}

Change process is the technique and process used to plan, implement and evaluate changes in a business operation to achieve a certain goal. For all organizational changes processes, there is a reason, force, cause, or source of the organizational change. Change management process is the sequence of steps or activities that a change management team or project leader would follow to apply change management to a project or change (Kuzmin, 2014; Andrushkiv, 2011). The most effective and commonly applied change, they have created a change management process that contains the following three phases:

Figure 1: Change management process steps

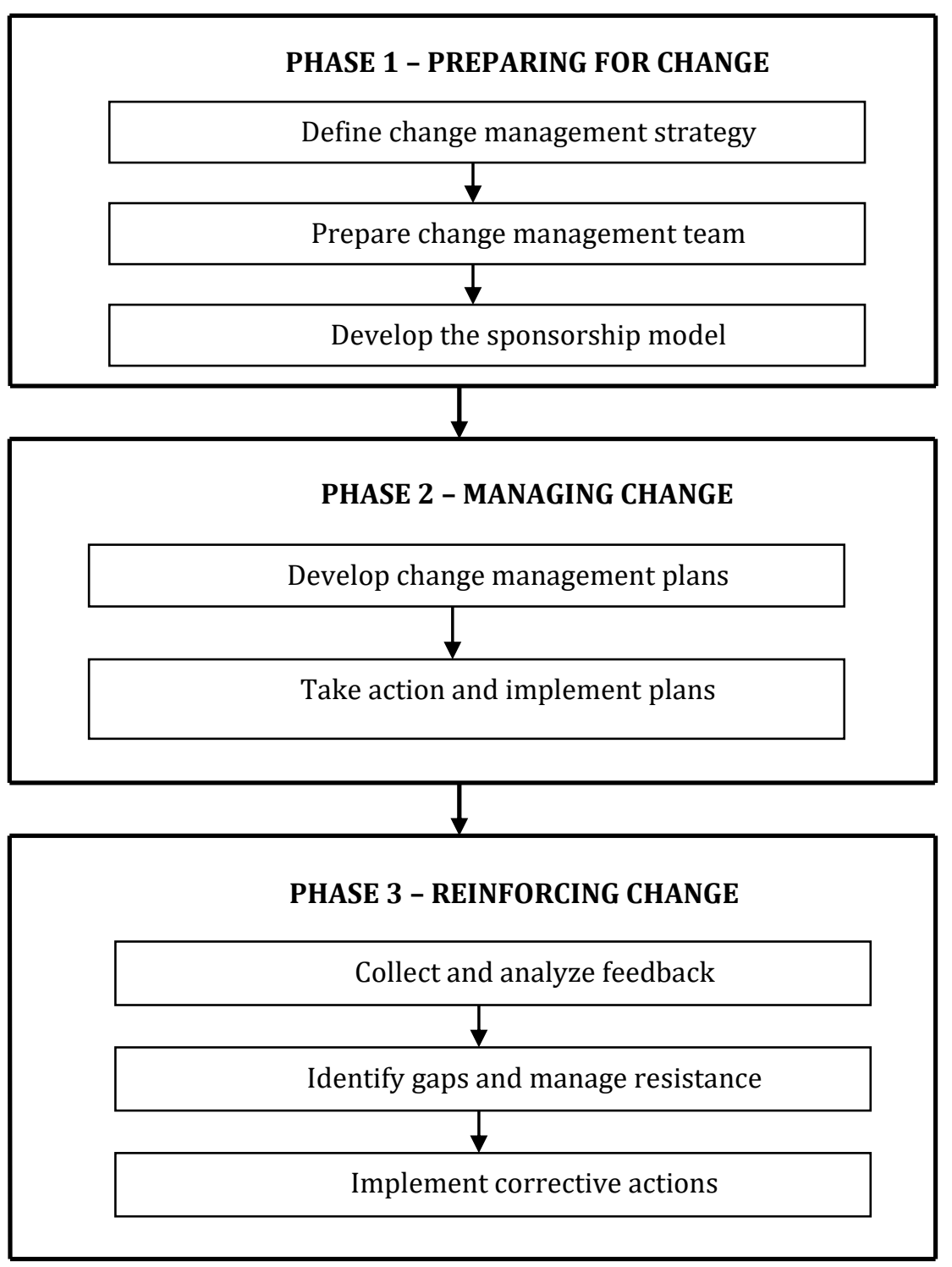

The first phase is preparing for change including preparation, assessment and strategy development. It's a series of readiness assessments and analysis provides the situational awareness required to manage the change at hand. The outputs of this phase are the customized change management strategy, the supporting structures (sponsorship and team model) and special tactics for the initiatives. Change management team is important because it is responsible for conducting a 
strategic review of its respective operations and organization to identify functions, programs and project which can be scaled down, phased out or abolished, or those which need to be strengthened.

The second phase is managing change including planning and change management implementation (Kuzhda, 2013). It's a process of creating and using the five change management tools, such as:

- communication plan aims at creating awareness and reinforcement, because communication is a tool used to build employee's awareness of the need for change and desire to participate and support the change as well as to reduce resistance and ensure methods of overcoming unusual and unexpected situations;

- Sponsorship roadmap lays out what the sponsor needs to be doing with the project team, managers, and employees. It also breaks down activities by the phase of the project, for example initiation, design, implementation and closeout. Effective sponsorship is needed to create an awareness of the need for change and is critical in building the desire to participate and support the change with each employee;

- Coaching plan outlines the steps for involving managers in change management activities. First, it lays out how the project team and change management resource will build commitment, train and skill up managers and supervisors related to their role in a change. The coaching sessions are crucial to getting employees and the organization moving forward with change adoption;

- Training plan is focused on building skills and capabilities and addressed knowledge and ability. Training is an important part of creating successful change, but must come after sufficient awareness and desire already exist;

- Resistance management plan includes the steps that organizations and managers can take to prevent and mitigate the impact of resistance. The resistance management plan also identifies who will be involved in managing resistance and how to prepare them to intervene.

The third phase is reinforcing change covering the mechanisms that are established for gathering feedback, identifying resistance, correcting gaps and measuring adoption and compliance. This holistic process ensures that best practices are incorporated, important steps are not missed and lessons learned are applied to speed up the change management.

Depending on the type of change, measuring change management process effectiveness has long been considered a lofty attempt (Kondalkar, 2013). It can be difficult to put in place measurement systems and metrics that provide solid data and information on how change is progressing, but there are practitioners leading the way. In fact, measuring the people side of change is becoming an expectation and even a requirement in many organizations (Reiss, 2012).

The table below contains the main metrics which a manager uses to track change management process effectiveness. These metrics can be broken into three groups: individual employee, overall project performance and change management activity metrics.

\begin{tabular}{|l|l|l|}
\hline \multicolumn{1}{|c|}{$\begin{array}{c}\text { Individual employee } \\
\text { metrics: }\end{array}$} & \multicolumn{1}{c|}{$\begin{array}{c}\text { Overall project } \\
\text { performance metrics: }\end{array}$} & $\begin{array}{c}\text { Change management } \\
\text { activity metrics: }\end{array}$ \\
\hline $\begin{array}{l}\text { 1. Employee awareness and } \\
\text { understanding of the change }\end{array}$ & $\begin{array}{l}\text { 1. Project performance } \\
\text { measurements }\end{array}$ & $\begin{array}{l}\text { 1. Tracking of change } \\
\text { management activities } \\
\text { conducted according to plan }\end{array}$ \\
\hline $\begin{array}{l}\text { 2. Employee engagement in change } \\
\text { management process }\end{array}$ & $\begin{array}{l}\text { 2. Progress and adherence to } \\
\text { plan }\end{array}$ & $\begin{array}{l}\text { 2. Training tests and } \\
\text { effectiveness measures }\end{array}$ \\
\hline $\begin{array}{l}\text { 3. Employee feedback and the level } \\
\text { of employee resistance to change }\end{array}$ & $\begin{array}{l}\text { 3. Business and change } \\
\text { readiness }\end{array}$ & $\begin{array}{l}\text { 3. Training participation and } \\
\text { attendance numbers }\end{array}$ \\
\hline $\begin{array}{l}\text { 4. Quantity of requests for support } \\
\text { during the change process }\end{array}$ & $\begin{array}{l}\text { 4. Benefit realization and } \\
\text { profitability index }\end{array}$ & 4. Resistance to change level \\
\hline $\begin{array}{l}\text { 5. Employee readiness assessment } \\
\text { results }\end{array}$ & $\begin{array}{l}\text { 5. Adherence to timeline and } \\
\text { speed of execution }\end{array}$ & $\begin{array}{l}\text { 5. Communication } \\
\text { effectiveness }\end{array}$ \\
\hline
\end{tabular}

One of the most unpredicted problems which business executives face is employee resistance to change. Such resistance may take a number of forms: persistent reduction in output and employee productivity, increase employee turnover, chronic quarrels and conflicts, sullen hostility, slowdown strikes, and, of course, the expression of a lot of other reasons why the change will not work. Even the more petty forms of this resistance can be troublesome.

Resistance to organizational change is the action taken by individuals and groups when they perceive that a change that is occurring as a threat to them. The company executives should understand different resistance states, identify the causes of change resistance and forms of change 
resistance (Kuzhda, 2014). Resistance to change may be defined as a cognitive state, an emotional state and behavioural state.

Cognitive state refers to the negative mind set toward the change. Cognitive resistance to change occurs as an individual perceives how the change will affect their likelihood of voicing ideas about organizational change. Signals of cognitive resistance may include limited or no willingness to communicate about or participate in change activities (such as those involving planning change, resource allocations, or change implementation) (Harigopal, 2006).

Emotional state addresses the emotional factors, such as frustration and aggression, which are caused by the change. Emotional resistance to change occurs as an individual balances emotions during change. Emotions about change are entrenched in an organization's values, beliefs, and symbols of culture. Signals of emotional resistance include a low emotional commitment to change leading to inertia or a high emotional commitment leading to chaos (Harigopal, 2006).

Behavioural state refers to the action or inaction towards the change. Behavioural resistance to change is an integration of cognitive and emotional resistance that is manifested by less visible and more covert actions toward the organizational change. Signals of behavioural resistance are the development of rumors and other informal or routine forms of resistance by individuals (Harigopal, 2006).

Also, understanding the different types of resistance will help managers in preparing employees for change. Let's take a look at different types of resistance to change in the organization.

Logical and rational resistance - these resistances are the outcomes of disagreement with rational facts, rational reasoning, logic and science. These arise from the actual time and effort required to adjust to change including new job duties that must be learned. Logical resistance to change includes the following: time required to adjust, extra efforts to relearn, possibility of less desirable condition, economic costs of change and questionable technical feasibility of change (Petrova, 2008).

Psychological resistance - these types of resistances are typically based on emotion and attitude. It is internally logical from the perspective of the employee attitude and feelings about change. Employees may fear the unknown, mistrust management, or feel that their security and ego needs are threatened. Even though management may believe that there is no justification for these feelings they are very rational to employees, and as such mangers must deal with them. Psychological or emotional resistance may take place in the following manner: fear of unknown, low tolerance of change, dislike of management/change agent, lack of trust in other, need for security and desire for status quo (Petrova, 2008).

Sociological resistance happens when it is seen as a product of challenge to group interests, norms, and values. Sociological resistance includes the following: employee's coalitions, opposing group values, vested interest and desire to retain existing friendships (Petrova, 2008).

Managing resistance to change is important part for success of any change effort in each company. Resistance in any form is intended to protect the employee from the perceived or real effects of change. Dealing with resistance in large part will depend on timely recognition of the real causes of resistance to change that can be broken into individual and organizational. Let's take a look at different forms and causes of change resistance.

Individual change resistance is the refusal of a single employee to fully support and participate in change activities. Individual causes of resistance to change reside in basic human characteristics such as perceptions, personalities, and needs. The following summarizes seven reasons why individuals may resist change (Kuzhda, 2013).

1. Habits. Employees work in large part is based on habits, and work tasks are performed in a certain way based on those habits. Organizational changes require shifts of those habits and because of that dissatisfaction from the changes.

2. Job's security. Organizational change can eliminate some work places or produce technological excess, layoffs and so on. People with a high need for security are likely to resist change because it threatens their feeling of safety. For example, when a company announces personnel cutbacks or introduces new robotic equipment, many employees may fear that their jobs are in jeopardy.

3. Economic factors. Organizational changes sometimes can be seen from the employee's side simply as something that will decrease their salary or other economic privileges that some workplace brings to them in the moment before implementation of the change process. It is normal to expect that those people who feel that they will lose the portion of their salary will resist the change.

4. Fear of unknown. Organizational change in many cases leads to uncertainty and some dose of fear. It is normal people to feel fear of uncertainty. When employees feel uncertainty in a process 
of transformation, they think that changes are something dangerous. This uncertainty affects organizational members to resist the proposed change.

5. Selective information processing. Employees usually doing selective information processing, or hear only something that they want to hear. They simply ignore information that is opposite of the current situation, and with this, they are preventing to accept important aspects of proposed changes, and it affects appearing resistance to change.

6. Increasing workload. In the process of organizational change, employees except for normal work activities usually will be loaded with activities of a new change process. These increasing workloads affect appearing resistance to change.

7. Threat to interpersonal relations. Employees are often friends with each other and they have a strong social and interpersonal relationship inside and outside organization. If an organizational change process can be seen as a threat to these powerful social networks in the organization, the affected employees will resist to that change.

Organizational change resistance is the tendency for a group of employees to reject an attempted change, even if that change is promoted over a long period of time by a substantial fraction of the employees. Organizational causes of resistance to change relate to organization's strategy, policy, rules and include the following (Kuzmin, 2014):

1. Structural inertia. Organizations have built-in mechanisms to produce stability. For example, the selection process systematically selects certain people in and certain people out. Training and other socialization techniques reinforce specific role requirements and skills. Formalization provides job descriptions, rules, and procedures for employees to follow. The people who are hired into an organization are chosen for fit; they are then shaped and directed to behave in certain ways. When an organization is confronted with change, this structural inertia acts as a counterbalance to sustain stability.

2. Limited focus of change. Organizations are made up of a number of interdependent subsystems. It's impossible to change one without affecting the others. For example, if management changes the technological processes without simultaneously modifying the organization's structure to match, the change in technology is not likely to be accepted. So, limited changes in subsystems tend to get nullified by the larger system.

3. Group inertia. Every organization has their own mechanisms as a rules, policies, and procedures. Even though individuals want to change their behaviour, these mechanisms in many cases can resist to the proposed changes.

4. Threat to expertise. Organizational changes in many cases result in personal discomfort and make employee's life more difficult. They make a transfer from the comfort of the status quo to discomfort of the new situation. Employees have skills and expertise to do an old job without some special attention to accomplishing the task. Each new task requires forgetting the old methods of doing the job and learning new things that lead to waste of energy, and causes dissatisfaction.

5. Threat to established power relationship. Any redistribution of decision-making authority can threaten long-established power relationships within the organization. The introduction of participative decision making or self-managed work teams is the kind of change that is often seen as threatening by supervisors and middle managers.

6. Threat to established resource allocations. With organizational changes, some groups, departments or sectors in the organization can receive more resources while the others will lose. So, this will bring resistance from the individuals, groups or departments who will lose some of there currently available resources. Those groups in the organization that control sizable resources often see change as a threat. They tend to be content with the way things are. Will the change, for instance, mean a reduction in their budgets or a cut in their staff size? Those that most benefit from the current allocation of resources often feel threatened by changes that may affect future allocations.

\section{Research methodology}

The main overall methodological approach used in this study concerns the estimation of resistance to change through examining the change formula and the experts answer questionnaires, selecting and ranking causes of resistance to change. In the current climate many companies are dealing with difficult situations and factors while implementing changes. Three factors must be present for meaningful organizational change to take place. Diagnosing resistance to change is the process of assessing factors affecting the organizational change. Beckhard and Harris put these factors into a change formula that provides a model to assess the relative strengths affecting the likely success of organizational change programs (McCalman, 2016). 
This seems to be a simple statement, but it's surprisingly powerful when used to structure a case for change. Let's define each element:

1. Dissatisfaction with the current situation. Employees have to feel dissatisfied with the current situation before a successful change can take place. Without satisfaction, no one will likely feel very motivated to change.

2. Desirability of proposed change. The proposed solution must be attractive, and people need to understand what it is. If a team doesn't have a clear vision of what things will be like after the change, and why things will be better, then they probably won't be willing to work to deliver it. The clearer and more detailed vision, the more likely it is that the team will want to agree with the change and move forward.

3. Practicality of the change. People need to believe that the proposed changes are realistic and doable. It's not necessary, or even practical, to try and plan out the whole thing in detail, but a high level description of how to get there with clear first steps, should be in place.

4. Resistance to change includes people's beliefs in the limits of the change, stubbornness toward any change, and general inertia or lack of interest at the beginning.

The change equation is used at the beginning or at any time during a change programme.

Diagnosing causes of resistance to change is the process of identifying significant and weighty causes of resistance to change by properly using the methods of expert survey and ranking causes of resistance to change. We propose methodological approach that includes the following steps in diagnosing causes of resistance to change:

$1^{\text {st }}$ step: Expert survey is a structured communication technique or method which relies on a panel of experts. The experts answer questionnaires, select significant and weighty causes of resistance to change. The experts are the internal or external change agents. Internal change agents are the managers or employees who are appointed to oversee the change process. External change agents are the outside consultants who bring an outsider's objective view to the organization.

$2^{\mathrm{d}}$ step: Ranking causes of resistance to change is a processing of survey results. This method consists of the average rank method or median rank method.

$3^{\mathrm{d}}$ step: Finding ways to deal with the resistance to change that are some common practices used to prevent, reduce and overcome resistance to change in the organization.

\begin{tabular}{|c|c|c|c|c|c|c|c|}
\hline \multirow{3}{*}{ № } & \multirow{3}{*}{$\begin{array}{c}\text { Causes of resistance to } \\
\text { change }\end{array}$} & \multicolumn{6}{|c|}{ Experts / Scores } \\
\hline & & \multirow{2}{*}{ 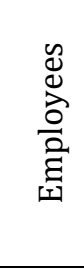 } & \multirow{2}{*}{ 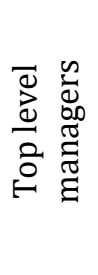 } & \multirow{2}{*}{ 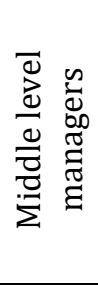 } & \multirow{2}{*}{ 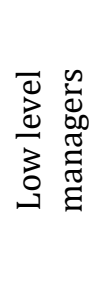 } & \multicolumn{2}{|c|}{ Consulting agency } \\
\hline & & & & & & $\begin{array}{c}\text { Group of } \\
\text { consultants } \\
1\end{array}$ & $\begin{array}{c}\text { Group of } \\
\text { consultants } \\
2\end{array}$ \\
\hline 1 & $\begin{array}{l}\text { Skepticism about the } \\
\text { need of change }\end{array}$ & 100 & 70 & 60 & 80 & 80 & 60 \\
\hline 2 & $\begin{array}{l}\text { Economic factors } \\
\text { (decrease in salary) }\end{array}$ & 100 & 50 & 70 & 100 & 80 & - \\
\hline 3 & Increasing workload & 100 & 40 & 90 & 90 & - & \\
\hline 4 & Limited resources & 90 & 40 & 70 & 60 & 80 & 60 \\
\hline 5 & Fear of unknown & 100 & 60 & 80 & 100 & 70 & 80 \\
\hline 6 & $\begin{array}{l}\text { Misunderstanding the } \\
\text { process }\end{array}$ & 70 & 20 & 40 & 50 & 60 & - \\
\hline 7 & $\begin{array}{l}\text { Mistrust to initiators of } \\
\text { change }\end{array}$ & 80 & 30 & 40 & 60 & 50 & 30 \\
\hline 8 & $\begin{array}{l}\text { Threat to interpersonal } \\
\text { relations }\end{array}$ & 80 & 20 & 30 & 40 & 50 & 80 \\
\hline 9 & Previous experience & 70 & 100 & 90 & 80 & 50 & 40 \\
\hline 10 & $\begin{array}{l}\text { Uninformed } \\
\text { employees }\end{array}$ & 80 & 30 & 50 & 40 & - & 60 \\
\hline
\end{tabular}

Source: author's computations

The application of above-described diagnosing method in business practice is given below.

A pipe manufacturing company introduces some kind of technological changes. It must select the most significant causes of resistance to change and the ways to deal with resistance to change. 
The employees, top level managers, middle level managers, low level managers and external change agents have participated in the survey of change resistance causes. After expert survey it was found ten weighty causes of resistance to technological change in the company: skepticism about the need of change, economic factors, increasing workload, limited resources, fear of unknown, misunderstanding the process, mistrust to initiators of change, threat to interpersonal relations, previous experience and uninformed employees.

100-point scale is used to assess the causes of resistance to change, where 10 is the score for the least important cause and 100 - is the score for the most significant cause. The results of expert survey are listed in the table below.

\section{Results}

Each of resistance causes gets its rank $r=\{1,2, \ldots, n\}$, where 1 - is the most significant cause that occurs most frequently, and $\mathrm{n}$ - is the least important cause. The ranking results are shown in the table 3. Low median rank indicates the most important causes of resistance to change. The survey processing results are shown in the table 4.

\begin{tabular}{|c|c|c|c|c|c|c|c|c|c|c|c|c|}
\hline \multirow{4}{*}{$\begin{array}{l}\text { Causes of } \\
\text { resistance to } \\
\text { change }\end{array}$} & \multicolumn{12}{|c|}{ Experts / Scores } \\
\hline & \multirow{2}{*}{\multicolumn{2}{|c|}{ Employees }} & \multirow{2}{*}{\multicolumn{2}{|c|}{$\begin{array}{l}\text { Top level } \\
\text { managers }\end{array}$}} & \multirow{2}{*}{\multicolumn{2}{|c|}{$\begin{array}{c}\text { Middle } \\
\text { level } \\
\text { managers }\end{array}$}} & \multirow{2}{*}{\multicolumn{2}{|c|}{$\begin{array}{l}\text { Low level } \\
\text { managers }\end{array}$}} & \multicolumn{4}{|c|}{ Consulting agency } \\
\hline & & & & & & & & & \multicolumn{2}{|c|}{$\begin{array}{c}\text { Group of } \\
\text { consultants } \\
1\end{array}$} & \multicolumn{2}{|c|}{$\begin{array}{c}\text { Group of } \\
\text { consultants } \\
2\end{array}$} \\
\hline & 巳ั: & 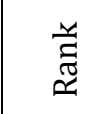 & $\stackrel{0}{\check{0}}$ & $\frac{\mathscr{y}}{\tilde{J}}$ & 巳ั & 䒕 & ¿ّ & 䒕 & ¿ั. & 苑 & ¿ั0 & 苑 \\
\hline $\begin{array}{l}\text { Skepticism about } \\
\text { the need of } \\
\text { change }\end{array}$ & 100 & 1 & 70 & 4 & 60 & 5,5 & 80 & 2,5 & 80 & 2,5 & 60 & 5,5 \\
\hline $\begin{array}{l}\text { Economic factors } \\
\text { (decrease in } \\
\text { salary) }\end{array}$ & 100 & 1,5 & 50 & 5 & 70 & 4 & 100 & 1,5 & 80 & 3 & - & - \\
\hline $\begin{array}{l}\text { Increasing } \\
\text { workload }\end{array}$ & 100 & 1 & 40 & 5 & 90 & 2,5 & 90 & 2,5 & - & - & 60 & 4 \\
\hline Limited resources & 90 & 1 & 40 & 6 & 70 & 4 & 60 & 5 & 80 & 2,5 & 80 & 2,5 \\
\hline Fear of unknown & 100 & 1,5 & 60 & 5 & 80 & 3 & 100 & 1,5 & 70 & 4 & - & - \\
\hline $\begin{array}{l}\text { Misunderstanding } \\
\text { the process }\end{array}$ & 70 & 1 & 20 & 6 & 40 & 4 & 50 & 3 & 60 & 2 & 30 & 5 \\
\hline $\begin{array}{l}\text { Mistrust to } \\
\text { initiators of } \\
\text { change }\end{array}$ & 80 & 1,5 & 30 & 6 & 40 & 5 & 60 & 3 & 50 & 4 & 80 & 1,5 \\
\hline $\begin{array}{l}\text { Threat to } \\
\text { interpersonal } \\
\text { relations } \\
\end{array}$ & 80 & 1 & 20 & 6 & 30 & 5 & 40 & 3,5 & 50 & 2 & 40 & 3,5 \\
\hline $\begin{array}{l}\text { Previous } \\
\text { experience }\end{array}$ & 70 & 4 & 100 & 1 & 90 & 2 & 80 & 3 & 50 & 6 & 60 & 5 \\
\hline $\begin{array}{l}\text { Uninformed } \\
\text { employees }\end{array}$ & 80 & 1 & 30 & 5 & 50 & 3 & 40 & 4 & - & - & 70 & 2 \\
\hline
\end{tabular}

\section{Source: author's computations}

Conclusion is that the median rank method shows that the most significant and weighty causes of resistance to change are the economic factors (decrease in salary), increasing workload, uninformed employees, and fear of unknown. So, the top executives have to focus on these causes and find the effective ways to overcome them.

The study identifies proper education, effective communication, facilitation, motivation, negotiation, manipulation, co-optation and coercion as possible methods for managing resistance to change. The use of any of these methods or combination of some, however, depends on the type of organization, nature of resistance and stage of intervention. 
While every organization is different, we pointed out the most important approaches used to overcome resistance to change.

\begin{tabular}{|c|c|c|}
\hline Causes of resistance to change & Total ranks & Median rank \\
\hline 1. Skepticism about the need of change & 21 & 3,25 \\
\hline 2. Economic factors (decrease in salary) & 15 & 3 \\
\hline 3. Increasing workload & 15 & 2,5 \\
\hline 4. Limited resources & 21 & 3,25 \\
\hline 5. Fear of unknown & 15 & 3 \\
\hline 6. Misunderstanding the process & 21 & 3,5 \\
\hline 7. Mistrust to initiators of change & 21 & 3,5 \\
\hline 8. Threat to interpersonal relations & 21 & 3,5 \\
\hline 9. Previous experience & 21 & 3,5 \\
\hline 10. Uninformed employees & 15 & 3 \\
\hline
\end{tabular}

Source: author's computations

1. Education and communication. To inform and educate staff about the change beforehand, early approaches and communication helps stakeholders see the rationale for change, which also reduces unsupported and incorrect rumors. If people's working style or habits need to change, the employees should be noted instead of being automatically put up to change (Kuzhda, 2013).

2. Participation and involvement. When employees are involved in decision-making, it can help to motivate the workforce. But this is a time consuming effort where it involves lots of consultations so that the workforce can accept this change. Having employees involved in change always eases the process because they have a say in what should be changed. This will help them ease into the change process because they would be changing to something that they want, thus motivating them to adapt (Pashchenko, 2014).

3. Facilitation and support. Another way that managers can deal with potential resistance to change is by being supportive. This process might include providing training in new skills, or giving employees time off after a demanding period, or simply listening and providing emotional support (Stepanenko, 2016).

4. Negotiations and agreement. Another way to deal with resistance is to offer incentives to active or potential resisters. For instance, management could give an employee a higher wage rate in return for a work rule change; it could increase an individual's pension benefits in return for an early retirement.

5. Manipulations and co-option. Manipulation, in this context, normally involves the very selective use of information and the conscious structuring of events. One common form of manipulation is co-optation. Co-opting an individual usually involves giving him or her desirable role in the design or implementation of the change. Co-opting a group involves giving one of its leaders, or someone it respects, a key role in the design or implementation of a change. This is not a form of participation, however, because the initiators do not want the advice of the co-opted, merely his or her endorsement (Kuzmin, 2014).

6. Explicit and implicit coercion. This is a last resort strategy if employees resist against change. Coercion can be used by managers to force staff to accept change. Examples include transfer of employees, dismissals or not promoting them.

\section{Conclusions}

It is significant to mention that that in business environment, the one thing any company can be assured of is change. If an organization experiences change it may also need to implement new business strategies, which can create resistance among employees. Many times, after the organizational change is introduced and met resistance, the executives say that "they saw when reaction coming". They need to know where resistance can be expected (department, team or phrase of change management process), whether the department or team can impact on change process differently than others, and what causes of resistance change depending on how each department or team is related to the change.

The phrases of change management process such as preparing for change, managing change and reinforcing change has been described and the place of resistance to change in the change management process has been identified. 
Depending on the type of change, measuring change management process effectiveness is important in order to provide quantitative data and information on how change is progressing. The individual employee, overall project performance and change management activity metrics have been pointed out in the measuring change management process effectiveness.

Different resistance states, causes of change resistance and forms of change resistance have been emphasized in the change management process. The proposed diagnosing model has been used to identify significant and weighty causes of resistance to change by using the expert survey and ranking causes of resistance to change. The ways to reduce and overcome resistance to change have been explained.

\section{Appendix A. Supplementary material}

Supplementary data associated with this article can be found, in the online version, at http://dx.doi.org/10.14254/jems.2016.1-1.5.

\section{Funding}

The authors received no direct funding for this research.

\section{Citation information}

Kuzhda, T. (2016). Diagnosing resistance to change in the change management process. Economics, Management and Sustainability, 1(1), 49-59. doi:10.14254/jems.2016.1-1.5.

\section{References}

Anderson, D. L. (2010). Organization Development: The Process of Leading Organizational Change. SAGE Publications Inc.

Andrushkiv, B., Vovk, J., Pohaydak, O., \& Fedyshyn, I. (2011). Crisis of Relationship in General Theory of Crisis. Journal of International Studies, 4(1), 18-25.

Cummings, T. G., \& Worley, C. G. (2009). Organization Development and Change. Cengage Learning.

Harigopal, K. (2006). Management of Organizational Change: Leveraging Transformation. SAGE Publications.

Kondalkar, V. G. (2013). Organization Effectiveness and Change Management. PHI Learning Pvt. Ltd.

Kuzhda, T. (2013). Etapy uspishnogo upravlinia organizatsiynymy zminamy na pidpryemstvi. [Steps for successful organizational change management at the enterprise]. Galytskyi ekonomochnyi visnyk = Galician economic bulletin, 2(41), 66-72. [in Ukrainian].

Kuzmin, O. (Ed.) (2014). Upravlinia zminamy [Change management]. Lvivska Politechnika. Ukraine [in Ukrainian].

Lysun, Y.V., \& Mikh, O.M. (2015) Formuvania systemy upravlinia zminamy na pidpryemstvi yak chynnyk strategichnogo partnerstva [Formation of the change management system in the enterprise as a factor of strategic partnership]. Naukovyi visnyk Mignorodnogo humanitarnogo universytetu = Scientific Journal of International Humanitarian University, 2(14), 97-100. [in Ukrainian].

McCalman, J., Paton, R.A. \& Siebert, S. (2016). Change Management: A Guide to Effective Implementation. 4th edition. Sage: London UK.

Oleksiv, I., \& Lisovych T. (2013). Teoretychni zasady zdiysnenia organizatsiyno-ekonomichnych zmin na pidpryemstvi [Theoretical foundations for performing organizational and economic changes on the enterprise]. Lviv Polytechnic National University, 77-82. [in Ukrainian].

Pashchenko, O. (2014). Suchasni metody upravlinia zminamy na pidpryemstvi [The modern methods of change management at the enterprise]. Visnyk Zhytomyrskogo derzhavnogo technologichnogo universytetu = Zhytomyr State Technological University Bulletin, Series Economic Science, 3, 170-178. [in Ukrainian].

Petrova, I., \& Polishchuk, V. (2008). Upravlinia zminamy [Change management]. Lviv. Ukraine. [in Ukrainian]. 
Reiss, M. (2012). Change Management: A Balanced and Blended Approach. Books on Demand.

Stepanenko, S.V. (2016). Formuvania mechanizmu upravlinia organizatsiynymy zminamy

[Formation of organizational change management mechanism]. Actual problems of innovative economy, 3, 60-67. [in Ukrainian].

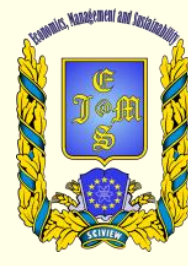

() 2016 Economics, Management and Sustainability. All rights reserved.

This open access article is distributed under a Creative Commons Attribution (CC-BY) 4.0 license.

You are free to:

Share - copy and redistribute the material in any medium or format Adapt - remix, transform, and build upon the material for any purpose, even commercially.

The licensor cannot revoke these freedoms as long as you follow the license terms.

Under the following terms:

Attribution - You must give appropriate credit, provide a link to the license, and indicate if changes were made.

You may do so in any reasonable manner, but not in any way that suggests the licensor endorses you or your use.

No additional restrictions

You may not apply legal terms or technological measures that legally restrict others from doing anything the license permits.

Economics, Management and Sustainability (ISSN: 2520-6303) is published by Scientific Publishing House "CSR", Poland, EU and Scientific Publishing House "SciView", Ukraine

Publishing with JEMS ensures:

- Immediate, universal access to your article on publication

- High visibility and discoverability via the JEMS website

- Rapid publication

- Guaranteed legacy preservation of your article

- Discounts and waivers for authors in developing regions

Submit your manuscript to a JEMS at http://jems.sciview.net or submit.jems@sciview.net 